\title{
PELATIHAN DAUR ULANG SAMPAH PLASTIK MENJADI KERAJINAN UNIK DI DESA PEMATANG TIGA KECAMATAN PEMATANG TIGA KABUPATEN BENGKULU TENGAH
}

\author{
Dian Mardiati Sari, SE.,M.Si*1, Meirita Sari, M.Pd.Si ${ }^{2}$, Reno Supardi, M.Kom ${ }^{3}$ \\ ${ }^{1}$ Universitas Dehasen, Bengkulu, Indonesia \\ ${ }^{2,3}$ Fakultas Ilmu Komputer Universitas Dehasen Bengkulu, Bengkulu, Indonesia
}

Email: *dian_kicky@yahoo.co.id

\begin{abstract}
ABSTRAK
Permasalahan sampah menjadi problema klasik yang selalu dihadapi oleh penduduk terutama di wilayah Desa Pemtang Tiga Bengkulu Tengah. Karena kuantitas maupun tingkat bahayanya, sampah terutama sampah plastik yang tersusun dari bahan kimia sukar diuraikan sehingga berbahaya bagi lingkungan, untuk itu perlu dilakukan pengolahan sampah untuk mengubah sampah plastik menjadi kerajinan yang memiliki nilai jual dan estetika. Metode yang digunakan dalam program pemanfaatan limbah plastik sebagai kerajian adalah survey analisis situasi dan pelaksanaan penyuluhan dan pelatihan. Implemetasi hasil proses pengolahan sampah yang berasal dari kemasan plastik menjadi kerajinan tangan di Desa Pematang Tiga Bengkulu Tengah dilakukan untuk meningkatkan kreatifitas serta keterampilan warga terutama ibu-ibu rumah tangga, pemuda pengangguran dan anak-anak yang putus sekolah. Selain itu juga dapat meminimalisir pencemaran lingkungan sehingga warga Desa Pematang Bengkulu Tengah dapat lebih peduli terhadap kebersihan lingkungan. Melalui pelatihan dan pendampingan pembuatan kreasi pemanfaatan sampah yang berasal dari kemasan plastik warga lebih punya pengetahuan mengenai peluang usaha yang dapat tercipta melalui kreatifitas dan keterampilan tersebut agar tingkat ekonomi warga Desa Pematang Bengkulu Tengah menjadi lebih tinggi.
\end{abstract}

Kata Kunci: Sampah plastik, estetika, kreatifitas

\section{PENDAHULUAN}

Desa Pematang Tiga adalah merupakan salah satu desa dalam Kecamatan Pematang Tiga Kabupaten Bengkulu Tengah Provinsi Bengkulu. Merupakan satu dari tiga belas Desa yang terdapat pada kecamatan Pematang Tiga, yang terletak di bagian utara Kabupaten bengkulu tengah. Luas wilayah Provinsi Bengkulu mencapai 32.365,6 kilometer persegi. Wilayah Provinsi Bengkulu memanjang dari perbatasan Provinsi Sumatera Barat sampai Provinsi Lampung dan jaraknya Lebih kurang 567 kilometer.

Dewasa ini, sampah menjadi salah satu permasalahan yang cukup sulit di tangani di Indonesia. Hal ini terjadi karena kebiasaan masyarakatnya sebagai konsumen yang selalu menghasilkan sampah terutama plastik pada setiap pemakaian produk. Seiring dengan perkembangan teknologi kebutuhan plastik terus meningkat, plastik merupakan bahan anorganik buatan yang tersusun dari bahanbahan kimia yang sukar diuraikan sehingga berbahaya bagi lingkungan. Sampah tersebut menjadi permasalahan lingkungan karena kuantitas maupun tingkat bahayanya mengganggu kelangsungan makhluk hidup. Oleh karena itu dengan mengubah sampah plastik menjadi barang yang dapat digunakan kembali dapat membantu mengurangi pencemaran lingkungan. Kreativitas pemanfaatan sampah 
plastik menjadi kerajinan tangan adalah solusi yang cukup baik untuk mengubah sampah plastik menjadi barang yang berguna kembali, bahkan memiliki nilai jual serta dapat dikreasikan menjadi barang yang mempunyai nilai estetika.

\section{METODE}

Metode yang digunakan dalam program pemanfaatan limbah plastik sebagai kerajinan tangan di Desa Pematang Tiga Bengkulu Tengah ini terbagi menjadi beberapa tahap kegiatan yaitu:

1. Persiapan Kegiatan,

Penggunaan metode survei dan observasi langsung menjadi pilihan utama dalam pelaksanaan tahap persiapan ini. melalui metode ini maka diharapkan tim pengabdian dapat menangkap permasalahan yang ada di lokasi sasaran kegiatan. Selain itu pula akan mempermudah koordinasi dengan para pihak terkait dan masayarakat Desa Pematang Tiga. Pada tahapan ini, dimulai dengan pengurusan perizinan, pengumpulan data umum Desa Pematang Tiga dan survei lingkungan warga sekitarnya. Selain itu, tim pengabdian menjalani komunikasi dengan tokoh masyarakat dan pihakpihak yang berwenang agar kegiatan dapat diterima dan terlaksana dengan baik. Tahap persiapan kegiatan ini merupakan tahapan kesiapan administrasi dan koordinasi secara teknis sebelum pelaksanaan kegiatan.

2. Pelaksanaan Kegiatan

Pada tahap pelaksanaan kegiatan ini dilakukan dengan :

Penyuluhan, metode penyuluhan adalah proses komunikasi yang merupakan intervensi social yang melibatkan penggunaan komunikasi informasi secara sadar untuk membantu masyarakat membentuk pendapat mereka sendiri dan mengambil keputusan dengan baik. Melalui metode ini masyarakat Desa Pematang Tiga diberikan pemahaman terhadap permasalahan sampah plastik berupa dampak dan cara penanggulangan sampah plastik. Dengan adanya sesi penyuluhan maka diharapkan masyarakat Desa Pematang Tiga memiliki kepedulian tentang permasalahan sampah plastik dan pengetahuan dasar dalam mengolah sampah plastik menjadi produk kerajinan yang memiliki nilai ekonomi.

Diskusi dan Tanya jawab, untuk memperkuat pemahaman masyarakat tentang permasalahan sampah plastik dan cara pembuatan produk olahan dari sampah plastik maka perlu dilakukan diskusi Tanya jawab secara langsung antara masyarakat dan tim pengabdian.

3. Keterkaitan

Dengan adanya kegiatan ini diharapkan aka nada keterkaitan pada dinas-dinas yang berkopeten dalam mengembangkan sistem terpadu dalam pengelolaan sampah terutama mengenai daur ulang sampah khususnya sampah plastik, seperti dinas kebersihan, koperasi dan UKM, dan dinas perdagangan.

\section{HASIL DAN PEMBAHASAN}

Dalam pelaksanaan sebuah program atau kegiatan dibutuhkan aspek pendampingan yang akan mengukur keberhasilan dari program atau kegiatan tersebut. Bentuk kegiatan pendampingan tersebut adalah evaluasi. Kegiatan evaluasi adalah kegiatan yang mengivestigasi efektifitas program, menilai kontribusi program terhadap tujuan, menilai kebutuhan akan perbaikan, kelanjutan atau perluasan program yang harus dilakukan. Sementara itu, selain adanya evaluasi yang mengukur keberhasilan pelaksanaan kegiatan, perlu juga ditinjau aspek keberlanjutan dari kegiatan tersebut. Berikut gambaran umum keberhasilan dan keberlanjutan dari kegiatan pengabdian kepada masyarakat di Desa Pematang Tiga Kecamatan Pematang Tiga Kabupaten Bengkulu Tengah. 
a. Keberhasilan Kegiatan

Sampah plastik jika dapat dikelola dengan baik maka akan menghasilkan produk yang memiliki nilai ekonomis. Selama ini sampah plastik dianggap sebagai masalah lingkungan. Hal ini dikarenakan dari semua jenis sampah, sampah plastik yang paling sulit terurai. Sampah plastik baru terurai kembali dalam waktu 400 hingga 1000 tahun. Sampah plastik yang tercecer diberbagai tempat ini jika hanya dibiarkan akan menimbulkan masalah lingkungan. Namun ternyata, dalam timbunan sampah plastik ini terkandung harta karung yang bernilai jutaan bahkan triliunan rupiah jika bisa diolah dengan baik. Konsep pemahaman inilah yang ditekankan pada pelatihan mengenai kepedulian terhadap sampah plastik dilingkungan Desa Pematang Tiga. Pemateri memaparkan bahwa sampah plastik jika dikelola dengan baik akan dapat diubah bentuknya menjadi beberapa produk kerajinan yang bernilai ekonomis. Bentuk dari produk tersebut diantaranya adalah tas, dompet, tempat tissue, vas bunga, tempat pensil/ pulpen, dan pot bunga yang dapat dibuat dari beragam sampah plastik seperti bekas bungkus kopi sachet, bungkus detergen, botol minuman, dan juga kantong plastik.

Dari penjaringan secara acak terhadap peserta diperoleh informasi bahwa para peserta memiliki pemahaman yang bertambah mengenai aspek lain dari kebermanfaatan daur ulang sampah plastik yaitu diantaranya adalah dapat membuka lapangan kerja baru, meningkatkan pendapatan masyarakat melalui penjualan produk-produk hasil daur ulang sampah plastik, mencegah dan mengatasi pencemaran lingkungan dan mencegah timbulnya penyakit sehingga membantu terciptanya lingkungan yang bersih dan sehat, serta meningkatkan daya kreatifitas dan keterampilan masyarakat.

b. Keberlanjutan Kegiatan

Merubah budaya hidup dari suatu masyarakat yang sudah berlangsung lama tidaklah mudah. Perlu ada kerjsama semua pihak yang sifatnya masih dan terstuktur. Terkait dengan pengelolaan sampah plastik pun demikian, perlu dilakukan pelatihan secara intensif dalam bentuk kelompok-kelompok masyarakat sadar sampah yang dibentuk terlebih dahulu. Untuk itu peran pemerintah sangat penting dalam hal mendampingi agar program tersebut terlaksana.

\section{KESIMPULAN DAN SARAN}

\section{A. Kesimpulan}

Pelaksanaan kegiatan pengabdian kepada masayarakat di Desa Pematang Tiga Kecamatan Pematang Tiga Kabupaten Bengkulu Tengah berlangsung dengan tertib. Secara umum, pelaksanaan dapat dikategorikan baik dan sukses. Hal ini dapat dilihat dari antusias para peserta dalam mengikuti kegiatan ini. Dalam proses pelaksanaan kegiatan yang berlangsung selama tiga jam tersebut masyarakat desa pematang tiga banyak mendapatkan informasi mengenai pentingnya dalam pengelolaan sampah plastik yang benar dan bagaimana mengolah sampah plastik menjadi barang yang bernilai secara ekonomi. Keberhasilan kegiatan ini tercermin pula dari beragam partisipasi peserta baik secra langsung maupun secara tidak langsung. Peserta kegiatan memberikan baragam pertanyaan terkait pengelohan sampah plastik dan bagaimana teknik dalam membuat beragam kerajinan yang berbahan dasar sampah plastik. Melalui kegiatan penyuluhan dan praktek mendorong masyarakat desa pematang tiga untuk lebih peduli lingkungan dan berkreasi dengan beragam sampah plastik yang dimiliknya.

\section{B. Saran}

Perlu dilakukan pendampingan secara teknik terhadap kelompok masyarakat Desa yang berminat untuk mengelola sampah plastik menjadi benda yang bernilai ekonomi. Selain itu perlu adanya kerjasama antar lembaga terkait yang sifatnya bersinergi dalam koordinasi yang satu arah agar Desa Pematang Tiga dapat dijadikan sebagai Desa percontohan dalam pengelolaan plastik kedepannya. 


\section{DAFTAR PUSTAKA}

Artiningsih. 2008. Peran Serta Masyarakat dalam Pengelolaan Sampah Rumah Tangga (Studi Kasus di Sampingan dan Jomblang, Kota Semarang). Program Magister Lingkungan Universitas Dionegoro. Semarang

Chambers, R. 1995. Rural Development: Putting The Last First. London; New York: Longman.

Diana, S. Dkk(2017). PEMANFAATAN SAMPAH PLASTIK MENJADI PRODUK KERAJINAN TANGAN BERNILAI EKONOMIS BAGI REMAJA PUTUS SEKOLAH. Jurnal Vokasi, 1(1). ISSN : 2548 4117.

Ife, J. W. 1995. Community Development: Creating Community Alternatives-Vision, Analysis and Practice. Melbourne; Longman.

Suharto, Edi. 2005. Membangun Masyarakat Memberdayakan Rakyat. Bandung: PT. Refika Aditama.

Sumodiningrat, Gunawan. 2002. Pemberdayaan Masyarakat dan Jaring Pengaman Sosial. Jakarta: Gramedia.

Wrihatnolo, Randy R dan Dwidjowijoto, Rian Nugroho. 2007. Manajemen Pemberdayaan. Jakarta: PT. Elex Media Komputindo. 